\title{
Exploration of encapsulated probiotic for preparation of curd rice
}

\author{
G. Gandhi ${ }^{1}$, K. Khamrui ${ }^{1 *}$ and W. G. Prasad ${ }^{1}$ \\ ${ }^{1}$ Dairy Technology Division, National Dairy Research Institute, Karnal - 132 001, Haryana, India
}

\begin{abstract}
An attempt was made to develop probiotic curd rice where probiotic was added in the form of encapsulated bead. Inulin at a concentration of $3 \%$ was used as prebiotic for encapsulation of Lactobacillus rhamnosus CRD-11 in alginate beads. Microencapsulation had significantly $(\mathrm{p}<0.05)$ increased the viability of probiotic against low $\mathrm{pH}$, high bile and moderately high thermal conditions. For standardization of probiotic curd rice, levels of curd, rice and salt were varied and selection was made on the basis of sensory scores and probiotic count. According to full factorial design standardized levels of curd, rice and salt were 55, 50 and 0.75 parts respectively, for encapsulated probiotic curd rice (EPCR) whereas for probiotic curd rice (PCR) with probiotic in free form, levels were 55, 45 and 0.75 parts respectively. Cell count of probiotics encapsulated in alginate and inulin was $9.51 \mathrm{log} \mathrm{CFU} / \mathrm{mL}$, whereas poor survival of free cells were depicted by only $7.87 \log$ CFU/mL. Convincingly, microencapsulation improved the survival of probiotic under stressed conditions as well as in the curd rice.
\end{abstract}

Key words: Curd rice, Inulin, Microencapsulation, Prebiotics, Probiotics

\section{Highlights}

- Probiotic curd rice was developed by using encapsulated probiotic microorganism viz., Lactobacillus rhamnosus CRD 11.

- Encapsulation in alginate complex in presence of inulin has significantly improved its viability under stressed conditions.

- Addition of these encapsulated beads in dahi have markedly enhanced the probiotic count in curd rice.

- Count of probiotics encapsulated in alginate and inulin was $9.51 \log \mathrm{CFU} / \mathrm{mL}$ as compared to only $7.87 \log \mathrm{CFU} / \mathrm{mL}$ in non-encapsulated samples.

\section{INTRODUCTION}

As per FAO/WHO (2002) live microorganisms which when administered in adequate amounts confer health benefits to host are known as probiotics. Certain attributes must be possessed by them before they can be entitled as probiotic which includes their survivability at the site of action; their ability to proliferate and colonize (Ohashi and Ushida, 2009). For a probiotics to be used in food and beverages, it should fulfill certain criteria such as, viability during process and storage conditions; survival in gastrointestinal environment of the host and ability to provide health benefits to the host via fermentation in the small intestine (Praepanitchai et al., 2019).
Extreme processing and storage conditions may suppress the viability of probiotics which limits their usage but in view of their massive application in food industries it is imperative to cultivate new methods to preserve the viability of probiotics (Ozyurt and Otles, 2014).

A technique where one substance (active agent) is entrapped inside a layer of another substance (wall material) in order to provide protection and stimulate its controlled release is called microencapsulation (Nedovic et al., 2011). For encapsulation of probiotic cells the most appropriate manner in relation to control and flexible adjustment of the resultant capsule size is emulsion technique, where small quantity

*Corresponding Author, E mail: kaushik.khamrui@icar.gov.in 
of aqueous hydrocolloid-cell mixture is emulsified into larger quantity of vegetable oil. This emulsion is then broken down to produce microcapsules having cells entrapped within. Most commonly used naturally occurring biopolymer to be used in bacterial encapsulation is alginate because of its biocompatibility, mild gelling conditions and generally regarded as safe (GRAS) status (Cook et al., 2012).

Probiotics must survive through gastrointestinal tract and preserve their bioactivity, however, due to the presence of gastric acids and intestinal juices they are incapable of exerting their beneficial effect (Rokka and Rantamäki, 2010). Mandal et al., 2006 reported that microencapsulated Lactobacillus casei NCDC 298 in alginate beads had better survival rate than that of the probiotics without encapsulation at high bile salt concentrations and low $\mathrm{pH}$ levels and also under thermal conditions upto $65^{\circ} \mathrm{C}$. Gibson and Roberfroid (1995) defined prebiotics as non-digested food components, which through the stimulation of growth and/or activity of a single type or a limited amount of microorganisms residing in the gastrointestinal tract, improve the health condition of a host. Chief objective of prebiotic is to encourage the growth and activity of probiotics in the gastrointestinal tract (Markowiak and Elijewska, 2017). When such substances are used along with alginate in microencapsulation, either as coating material or as an additional layer, they can improve the viability of bacteria throughout the process of production and digestion and helps in controlling the release mechanisms inside the host because of potential synergy between probiotics and prebiotics.

Krasaekoopt and Watcharapoka (2014) reported that presence of inulin $(1.5 \%)$ and galacto-oligosaccharides in alginate beads coated with chitosan during microencapsulation of Lactobacillus species provides enhanced protection and viability of probiotic in yoghurt and fruit juice. Inulin and Plantago psyllium provided significant protection to the Lactobacillus plantarum when tested against gastric and intestinal conditions, hence offering the possibility of addition of these capsules inside different food products without effecting their viability of probiotic or their physicochemical characteristics (Peredo et al., 2016). Sabikhi et al. (2010) concluded that encapsulated cells of Lactobacillus acidophilus endured the artificial gastric conditions $(\mathrm{pH} 1.5$ for $2 \mathrm{~h}$ ) in much better way than that of the free cells of same strain. Curd rice is a famous Indian delicacy, an excellent source of nutrition because of its rich natural microbiota coming from dahi, as well as rice in it acts as a good bulking agent. However, none of such prebiotic loaded encapsulated probiotic Lactobacillus rhamnosus CRD-11 has been checked for its thermal stability and under gastrointestinal conditions. Their application in curd rice has also not been studied so far. Therefore, the objective of the study was to carry out the process of encapsulation of probiotic Lactobacillus rhamnosus CRD-11 and its application in production of probiotic curd rice.

\section{MATERIALS AND METHODS}

Bacterial strain: The probiotic strain used in study was Lactobacillus rhamnosus CRD-11 and dahi culture Streptococcus thermophillus NCDC 324 were procured from Dairy Microbiology Division, ICAR- National Dairy Research Institute, Karnal. The strains were maintained in MRS broth at $37^{\circ} \mathrm{C}$ and $42^{\circ} \mathrm{C}$ respectively.

\section{Encapsulation of Lactobacillus rhamnosus}

CRD-11: Microencapsulation of Lactobacillus rhamnosus CRD-11 in sodium alginate matrix was carried out by using emulsion method as suggested by Sheu et al. (1993). Encapsulates were prepared by using method given by Mandal et al. (2006).

Enumeration of free and encapsulated cells and encapsulation efficiency: All the enumerations were done using pour plate method as described by Houghtby et al. (1993). Encapsulation efficiency of the cells was 
calculated by following the equation and expressed as number of colony forming unit $(\mathrm{CFU} / \mathrm{mL}): \mathrm{EY}=\left(\log _{10} \mathrm{~N}_{1} / \log _{10} \mathrm{~N}_{0}\right) \times 100$, (where $\mathrm{N}_{1}$ is the number of entrapped bacterial cells inside the bead and $\mathrm{N}_{0}$ is the amount offree bacterial cells added into the alginate mixture during the preparation process).

Heat tolerance: Heat tolerance of free and encapsulated bacterial cells was studied by following the method as given by Ding and Shah (2007) exposing the probiotic bacteria to moderately high temperatures such as $65^{\circ} \mathrm{C}$ for $20 \mathrm{~min}, 70^{\circ} \mathrm{C}$ and $75^{\circ} \mathrm{C}$ for 2 minutes.

Acid tolerance: Acid tolerance of microencapsulated probiotic cells and a control consisting of free cells was studied using methods of Ding and Shah (2007).

Bile tolerance: Bile tolerance of free and encapsulated bacterial cells was calculated as per the method given by Rao et al. (1989).

Standardization of probiotic curd rice and encapsulated probiotic curd rice: Selection of ingredients for preparation of probiotic curd rice (PCR) was done by varying the levels of probiotic curd, rice and salt (Table 1). Rice was prepared by cooking them in open vessel, whereas probiotic curd was prepared using dahi culture (Streptococcus thermophiles NCDC 324) and probiotic culture (Lactobacillus rhamnosus CRD-11) in 1:1 proportion. The curd prepared was mixed with cooked rice and salt as per different combination obtained from full factorial design.

Standardization of curd rice was carried out using three ingredients namely, curd, rice and salt at three different levels. Full factorial design was used to design an experiment.
Standardization was done on the basis of sensory parameters such as flavour, colour, body and texture, overall acceptability and probiotic count. Probiotic (free or encapsulated) curd was added in milk at the time of inoculation with dahi culture.

Sensory analysis: Samples obtained during the course of investigation were analyzed by a trained panelists consisting of seven members from the scientific faculty of NDRI, Karnal, using a 9-point Hedonic scale.

Statistical analysis: Data was recorded in mean \pm S.D. of three replicates. A single factor analysis of variance (ANOVA) was used to calculate the SEM of the cell counts as well as the sensory scores. Significant differences between the means of cell counts were determined using Duncan test $(p \leq 0.05)$.

\section{RESULTS}

Effect of prebiotic on thermal tolerance: With the intention to enhance the metabolic activity of the probiotics during fermentation it was added in the encapsulation matrix along with sodium alginate. Levels of inulin addition varied from 1-6\% and most suitable level was decided on the basis of its ability to withstand thermal treatments viz., $65^{\circ} \mathrm{C} / 20 \mathrm{~min}, 70^{\circ} \mathrm{C} / 5 \mathrm{~min}$ and $75^{\circ} \mathrm{C} / 2 \mathrm{~min}$. It was observed that at $65^{\circ} \mathrm{C}$, highest viability of $9.54 \log \mathrm{CFU} / \mathrm{mL}$ was noted which was similar to that of $4 \%$ inulin level (9.19 $\log \mathrm{CFU} / \mathrm{mL}$ ). Trend in the viability of encapsulated $L$. rhamnosus $\mathrm{CRD} 11$ at $70^{\circ} \mathrm{C}$ and $75^{\circ} \mathrm{C}$ were similar to that of $65^{\circ} \mathrm{C}$. At $70^{\circ} \mathrm{C}$, highest viability of $9.70 \log \mathrm{CFU} / \mathrm{mL}$ was observed at $3 \%$ inulin concentration, whereas at $75^{\circ} \mathrm{C}$ highest viability of $9.75 \log \mathrm{CFU} / \mathrm{mL}$ at the same concentration. It was witnessed that enhancement in inulin concentration increased

Table 1. Level of ingredients for standardization of probiotic curd rice

\begin{tabular}{lllcl}
\hline S.No. & Variables & Levels \\
\hline 1 & Curd (parts) & 45 & 50 & 55 \\
2 & Cooked rice (parts) & 55 & 50 & 45 \\
3 & Salt (\%) & 0.75 & 1 & 1.25 \\
\hline
\end{tabular}


the thermal tolerance of the beads, apparently it was increasing till $3 \%$ after which the count tend to decrease. This may be attributed to the fact that with increasing concentration of inulin encapsulation efficiency was decreased. As shown in the Table 2, highest encapsulation efficiency of $96.30 \%$ was found at $3 \%$ inulin concentration. It is evident from the results that microencapsulation of probiotic with a protective layer increased their thermal stability. The statistical analysis of data indicated that significant $(p<0.05)$ difference exists between the survival of free and encapsulated probiotic during thermal treatment. Addition of prebiotic into alginate beads appeared to bestow better protection to the probiotics by imparting strength to the wall matrix under conditions of high temperature.

Effect of low pH: The effect of encapsulation on the survivability of probiotic bacteria under simulated gastric conditions ( $\mathrm{pH} \mathrm{1.5,2}$ and 3) as compared to that of free cells was studied. It was detected that in case of free cells significant difference $(\mathrm{p}<0.05)$ was observed in survivality of Lactobacillus rhamnosus CRD 11 at all $\mathrm{pH}$ conditions after 3 hours of incubation.

It was observed that viability of probiotic decreased significantly $(\mathrm{p}<0.5)$ after exposure to low $\mathrm{pH}$ after $3 \mathrm{hrs}$. In general, significant $(\mathrm{p}<0.05)$ decrease in the viability of cells was observed after $2 \mathrm{~h}$ of incubation. The viability of probiotic Lactobacillus rhamnosus CRD 11 decreased significantly $(\mathrm{p}<0.05)$ from $8.26 \mathrm{log}$ $\mathrm{CFU} / \mathrm{mL}$ to $5.55 \log \mathrm{CFU} / \mathrm{mL}$ after $3 \mathrm{~h}$ of incubation at $\mathrm{pH}$ 1.5. However, there was no significant decrease in the viability of the probiotic at $\mathrm{pH} 6.5$ as shown in Table 3. At $\mathrm{pH}$ 2 and $\mathrm{pH} \mathrm{3}$, significant $(\mathrm{p}<0.05)$ decrease in the viability of probiotic was observed. It was observed that viability of probiotic Lactobacillus rhamnosus CRD 11 was significantly $(\mathrm{p}<0.05)$ different at different $\mathrm{pH}$ conditions. At higher duration, viability was found to be least at lowest $\mathrm{pH}$ value.

Encapsulation of the probiotic led to increased tolerance of the probiotic against low $\mathrm{pH}$ conditions. As shown in the Table 3 at control $\mathrm{pH}$ of 6.5 the viability of encapsulated probiotic remain unchanged after $3 \mathrm{~h}$ of storage similar to that of free cells as shown in Table 3. As could be observed, at $\mathrm{pH} 3$ viability of microencapsulated probiotic decreased from $8.91 \log \mathrm{CFU} / \mathrm{mL}$ to $8.36 \log \mathrm{CFU} / \mathrm{mL}$ after $3 \mathrm{~h}$, whereas $6.9 \%$ reduction in the viability of the probiotic was observed from $8.88 \log \mathrm{CFU} / \mathrm{mL}$ to $8.26 \log \mathrm{CFU} / \mathrm{mL}$ at $\mathrm{pH} 2$ after similar duration of incubation. Highest reduction of $8.7 \%$ was observed at $\mathrm{pH} 1.5$ wherein the viability of $9.01 \log \mathrm{CFU} / \mathrm{mL}$ was reduced to $8.22 \log \mathrm{CFU} / \mathrm{mL}$. From the results it was observed that reduction in the viability of microencapsulated probiotic Lactobacillus rhamnosus CRD-11 was non-significant at $\mathrm{pH}$ 1.5 after $3 \mathrm{~h}$ of incubation as compared to free cells wherein the reduction was $32.80 \%$. Microencapsulation provides a physical boundary around the bacterial cell which offers a great deal of protection to its viability under stressed conditions such as low $\mathrm{pH}$.

Effect of high bile: Table 4 shows the effect of high bile salt concentrations on the viability of probiotic Lactobacillus rhamnosus CRD 11. It was observed that viability of probiotic decreased significantly $(\mathrm{p}<0.05)$ at $1 \%$ and $2 \%$ concentration of bile salts after $3 \mathrm{~h}$ of exposure as compared to control. It was observed that exposing the beads to $2 \%$ bile salt concentrations did not cause significant reduction in the viability whereas, viability of the beads in $1 \%$ bile salt solution reduced significantly $(\mathrm{p}<0.05)$ from $8.88 \log \mathrm{CFU} / \mathrm{mL}$ to $7.85 \log \mathrm{CFU} / \mathrm{mL}$ after same duration, implying $11.6 \%$ reduction. Encapsulation of probiotic was able to protect it significantly $(\mathrm{p}<0.05)$ from $1 \%$ bile salt concentration upto $2 \mathrm{hrs}$ with causing only $7.8 \%$ reduction in the viability from $8.88 \mathrm{log} \mathrm{CFU} / \mathrm{mL}$ to $8.18 \mathrm{log}$ $\mathrm{CFU} / \mathrm{mL}$. At $2 \%$ concentration of bile salt, the viability of the probiotic L. rhamnosus CRD11 was found to be significantly similar after $3 \mathrm{~h}$ of incubation. Reduction in the viable cell count was observed from $8.63 \mathrm{log} \mathrm{CFU} / \mathrm{mL}$ to 7.97 $\log \mathrm{CFU} / \mathrm{mL}$ after $3 \mathrm{~h}$ of exposure. 
Table 2. Effect of inulin concentration and heat treatment on probiotic beads

\begin{tabular}{ccccccc}
\hline $\begin{array}{c}\text { Inulin } \\
\text { concentration } \\
(\%)\end{array}$ & $\begin{array}{c}\text { Initial } \\
\text { cells } \\
(\mathbf{L o g 1 0})\end{array}$ & $\begin{array}{c}\text { Beads } \\
(\mathbf{L o g} 10)\end{array}$ & $\begin{array}{c}\mathbf{6 5}^{\circ} \mathbf{C} / \mathbf{2 0 m i n} \\
(\mathbf{L o g} 10)\end{array}$ & $\begin{array}{c}\mathbf{7 0}^{\circ} \mathbf{C} / \mathbf{5 m i n} \\
(\mathbf{L o g} \\
\mathbf{C F U / m L})\end{array}$ & $\begin{array}{c}\mathbf{7 5}^{\circ} \mathbf{C} / 2 m i n \\
(\log 10)\end{array}$ & $\begin{array}{c}\text { Encapsulation } \\
\text { efficiency (\%) }\end{array}$ \\
\hline 1 & 12.33 & 11.84 & $8.91 \pm 0.05^{\mathrm{d}}$ & $9.12 \pm 0.04^{\mathrm{b}}$ & $9.13 \pm 0.04^{\mathrm{ab}}$ & $96.02 \pm 0.12^{\mathrm{a}}$ \\
2 & 13.14 & 11.84 & $9.16 \pm 0.06^{\mathrm{c}}$ & $9.11 \pm 0.04^{\mathrm{b}}$ & $9.11 \pm 0.05^{\mathrm{a}}$ & $90.10 \pm 0.09^{\mathrm{b}}$ \\
3 & 12.17 & 11.72 & $9.54 \pm 0.08^{\mathrm{a}}$ & $9.70 \pm 0.09^{\mathrm{a}}$ & $9.75 \pm 0.07^{\mathrm{a}}$ & $96.30 \pm 0.13^{\mathrm{a}}$ \\
4 & 12.47 & 11.59 & $9.19 \pm 0.03^{\mathrm{ab}}$ & $9.22 \pm 0.14^{\mathrm{b}}$ & $9.28 \pm 0.08^{\mathrm{b}}$ & $92.94 \pm 0.11^{\mathrm{b}}$ \\
5 & 12.56 & 11.29 & $9.06 \pm 0.06^{\mathrm{c}}$ & $9.23 \pm 0.03^{\mathrm{b}}$ & $9.27 \pm 0.03^{\mathrm{b}}$ & $89.88 \pm 015^{\mathrm{bc}}$ \\
6 & 13.56 & 11.88 & $9.35 \pm 0.06^{\mathrm{b}}$ & $9.10 \pm 0.04^{\mathrm{b}}$ & $9.2 \pm 0.23^{\mathrm{b}}$ & $87.61 \pm 0.21^{\mathrm{c}}$ \\
\hline
\end{tabular}

Values are Mean \pm SD of three replications; ${ }^{\text {a-c }}$ Means with different superscripts vary significantly $(\mathrm{p}<0.05)$ within a column

Table 3. Effect of low pH on free and encapsulated probiotic

\begin{tabular}{ccccc}
\hline \multicolumn{5}{c}{ Free cells } \\
\hline Time/pH & Control & $\mathbf{1 . 5}$ & $\mathbf{2}$ & $\mathbf{3}$ \\
\hline 0 & $8.56 \pm 0.40^{\mathrm{Aa}}$ & $8.26 \pm 0.25^{\mathrm{Ac}}$ & $8.45 \pm 0.36^{\mathrm{Ac}}$ & $8.24 \pm 0.22^{\mathrm{Ac}}$ \\
1 & $8.59 \pm 0.34^{\mathrm{Aa}}$ & $7.61 \pm 0.44^{\mathrm{Bb}}$ & $7.81 \pm 0.70^{\mathrm{Bbc}}$ & $7.83 \pm 0.56^{\mathrm{Bbc}}$ \\
2 & $8.77 \pm 0.28^{\mathrm{Aa}}$ & $6.16 \pm 0.07^{\mathrm{Ca}}$ & $7.15 \pm 0.66^{\mathrm{Bab}}$ & $7.08 \pm 0.40^{\mathrm{Bab}}$ \\
3 & $8.85 \pm 0.38^{\mathrm{Aa}}$ & $5.55 \pm 0.45^{\mathrm{Ca}}$ & $6.38 \pm 0.30^{\mathrm{Ba}}$ & $6.55 \pm 0.35^{\mathrm{Ba}}$ \\
\hline \multicolumn{5}{c}{ Encapsulated cells } \\
\hline Time/pH & Control & $\mathbf{1 . 5}$ & $\mathbf{2}$ & $\mathbf{3}$ \\
\hline 0 & $8.45 \pm 0.25^{\mathrm{Aa}}$ & $9.01 \pm 0.56^{\mathrm{aA}}$ & $8.88 \pm 0.22^{\mathrm{Aa}}$ & $8.91 \pm 0.22^{\mathrm{Aa}}$ \\
1 & $8.49 \pm 0.29^{\mathrm{Aa}}$ & $8.44 \pm 0.53^{\mathrm{aA}}$ & $8.50 \pm 0.15^{\mathrm{abA}}$ & $8.80 \pm 0.15^{\mathrm{Aa}}$ \\
2 & $8.51 \pm 0.33^{\mathrm{Aa}}$ & $8.37 \pm 0.30^{\mathrm{Aa}}$ & $8.60 \pm 0.23^{\mathrm{abA}}$ & $8.62 \pm 0.23^{\mathrm{Aa}}$ \\
3 & $8.57 \pm 0.34^{\mathrm{aA}}$ & $8.22 \pm 0.62^{\mathrm{aA}}$ & $8.26 \pm 0.15^{\mathrm{Aa}}$ & $8.36 \pm 0.15^{\mathrm{Aa}}$ \\
\hline
\end{tabular}

Values are Mean \pm Standard Deviation of three replications; ${ }^{\mathrm{a}-\mathrm{c}}$ Means with different superscripts vary significantly $(\mathrm{p}<0.05)$ within a column; A-B: Means with different superscripts vary significantly $(\mathrm{p}<0.05)$ within a row

Table 4. Effect of high bile on free and encapsulated probiotic

\begin{tabular}{|c|c|c|c|}
\hline \multicolumn{4}{|c|}{ Free cells } \\
\hline $\begin{array}{c}\text { Time }(\mathrm{hr}) / \\
\text { bile conc. }(\%)\end{array}$ & control & 1 & 2 \\
\hline 0 & $8.56 \pm 0.07^{\mathrm{Aa}}$ & $8.04 \pm 0.39^{\mathrm{Abc}}$ & $8.14 \pm 0.35^{\mathrm{Ab}}$ \\
\hline 1 & $8.69 \pm 0.25^{\text {Аa }}$ & $7.61 \pm 0.30^{\mathrm{Bbc}}$ & $7.62 \pm 0.37^{\mathrm{Bb}}$ \\
\hline 2 & $8.75 \pm 0.30^{\mathrm{Aa}}$ & $6.92 \pm 0.65^{\text {Bab }}$ & $6.83 \pm 0.29^{\mathrm{Ba}}$ \\
\hline 3 & $8.79 \pm 0.42^{\text {Аa }}$ & $6.49 \pm 0.33^{\mathrm{Ba}}$ & $6.27 \pm 0.39^{\mathrm{Ba}}$ \\
\hline \multicolumn{4}{|c|}{ Encapsulated cells } \\
\hline $\begin{array}{l}\text { Time }(\mathrm{hr}) / \\
\text { bile conc. }(\%)\end{array}$ & control & 1 & 2 \\
\hline 0 & $8.19 \pm 0.41^{\mathrm{aB}}$ & $8.88 \pm 0.11^{\mathrm{bA}}$ & $8.63 \pm 0.24^{\mathrm{bA}}$ \\
\hline 1 & $8.02 \pm 0.74^{\mathrm{aA}}$ & $8.66 \pm 0.27^{\mathrm{bA}}$ & $8.42 \pm 0.48^{\mathrm{abA}}$ \\
\hline 2 & $8.20 \pm 0.81^{\mathrm{aA}}$ & $8.18 \pm 0.10^{\mathrm{abA}}$ & $7.82 \pm 0.33^{\mathrm{aA}}$ \\
\hline 3 & $8.48 \pm 0.46^{\mathrm{aA}}$ & $7.85 \pm 0.06^{\mathrm{aA}}$ & $7.96 \pm 0.32^{\mathrm{abA}}$ \\
\hline
\end{tabular}

Values are Mean \pm Standard Deviation of three replications; ${ }^{\mathrm{a}-\mathrm{c}}$ Means with different superscripts vary significantly $(\mathrm{p}<0.05)$ within a column; A-B: Means with different superscripts vary significantly $(\mathrm{p}<0.05)$ within a row 
Optimization of ingredients for probiotic curd rice and encapsulated probiotic curd rice

Probiotic curd rice: The organoleptic scores for different combinations of PCR are presented in Table 5. Highest value of flavour score was obtained for 55 parts of probiotic curd, 55 parts of rice and $1 \%$ salt, whereas lowest score was obtained with a combination of 45 parts curd, 55 parts rice and $1 \%$ salt. It was observed that positive correlation of curd content was highly significant $(\mathrm{p}<0.01)$ with the flavour scores. Effect of salt content was found to be highly significant $(p<0.01)$ on the flavour scores of PCR. Increase in the salt content led to decrease in the flavour scores. It was observed that better

Table 5. Sensory scores and probiotic count for probiotic curd rice (free cells)

\begin{tabular}{|c|c|c|c|c|c|c|c|c|}
\hline $\begin{array}{l}\text { Combi- } \\
\text { nation }\end{array}$ & Curd & Rice & Salt & Flavour & $\begin{array}{l}\text { Colour and } \\
\text { appearance }\end{array}$ & $\begin{array}{l}\text { Body and } \\
\text { texture }\end{array}$ & $\begin{array}{l}\text { Overall } \\
\text { acceptability }\end{array}$ & $\begin{array}{l}\text { Probiotic } \\
\text { count (log } \\
\text { CFU/g) }\end{array}$ \\
\hline$\overline{\mathrm{C} 1}$ & 45 & 45 & 0.75 & $7.83 \pm 0.035^{\mathrm{k}}$ & $7.82 \pm 0.021^{\text {ef }}$ & $7.67 \pm 0.026^{\mathrm{h}}$ & $7.84 \pm 0.040^{\mathrm{jk}}$ & $6.12 \pm 0.106^{\mathrm{bcd}}$ \\
\hline $\mathrm{C} 2$ & 45 & 45 & 1 & $7.48 \pm 0.025^{\mathrm{i}}$ & $7.84 \pm 0.025^{\mathrm{ef}}$ & $7.51 \pm 0.031^{\mathrm{efg}}$ & $7.50 \pm 0.035^{\mathrm{g}}$ & $7.83 \pm 0.061^{b}$ \\
\hline $\mathrm{C} 3$ & 45 & 45 & 1.25 & $6.82 \pm 0.020^{\mathrm{e}}$ & $7.71 \pm 0.026^{\mathrm{d}}$ & $7.30 \pm 0.025^{\mathrm{cd}}$ & $7.20 \pm 0.100^{\mathrm{def}}$ & $6.27 \pm 0.050^{\mathrm{a}}$ \\
\hline $\mathrm{C} 4$ & 45 & 50 & 0.75 & $7.86 \pm 0.023^{\mathrm{k}}$ & $8.03 \pm 0.058^{\mathrm{gh}}$ & $8.07 \pm 0.058^{\mathrm{kl}}$ & $7.50 \pm 0.045^{\mathrm{g}}$ & $6.80 \pm 0.068^{\mathrm{b}}$ \\
\hline $\mathrm{C} 5$ & 45 & 50 & 1 & $7.86 \pm 0.026^{\mathrm{k}}$ & $7.84 \pm 0.023^{\mathrm{ef}}$ & $8.00 \pm 0.000^{\mathrm{k}}$ & $7.82 \pm 0.015^{\mathrm{j}}$ & $6.31 \pm 0.021^{\mathrm{a}}$ \\
\hline C6 & 45 & 50 & 1.25 & $7.50 \pm 0.030^{\mathrm{i}}$ & $8.14 \pm 0.026^{\mathrm{ij}}$ & $7.85 \pm 0.026^{\mathrm{ij}}$ & $7.67 \pm 0.031^{\mathrm{hi}}$ & $6.18 \pm 0.060^{\mathrm{a}}$ \\
\hline $\mathrm{C} 7$ & 45 & 55 & 0.75 & $6.73 \pm 0.051^{\mathrm{d}}$ & $7.19 \pm 0.046^{\mathrm{c}}$ & $6.90 \pm 0.025^{\mathrm{b}}$ & $7.11 \pm 0.060^{\mathrm{d}}$ & $6.42 \pm 0.106^{\mathrm{a}}$ \\
\hline $\mathrm{C} 8$ & 45 & 55 & 1 & $6.12 \pm 0.108^{\mathrm{a}}$ & $6.61 \pm 0.040^{\mathrm{b}}$ & $6.09 \pm 0.081^{\mathrm{a}}$ & $5.49 \pm 0.023^{\mathrm{a}}$ & $6.22 \pm 0.070^{\mathrm{a}}$ \\
\hline C9 & 45 & 55 & 1.25 & $6.11 \pm 0.042^{\mathrm{a}}$ & $6.40 \pm 0.025^{\mathrm{a}}$ & $6.10 \pm 0.055^{\mathrm{a}}$ & $5.53 \pm 0.104^{\mathrm{a}}$ & $6.13 \pm 0.111^{\mathrm{a}}$ \\
\hline $\mathrm{C} 10$ & 50 & 45 & 0.75 & & $7.74 \pm 0.056^{\mathrm{d}}$ & & $7.65 \pm 0.031^{\mathrm{hi}}$ & $7.68 \pm 0.060^{\mathrm{fg}}$ \\
\hline $\mathrm{C} 11$ & 50 & 45 & 1 & $7.86 \pm 0.036^{\mathrm{k}}$ & $7.83 \pm 0.030^{\text {ef }}$ & $7.54 \pm 0.338^{\text {efgh }}$ & $8.05 \pm 0.050^{\mathrm{lm}}$ & $7.18 \pm 0.074^{\mathrm{cd}}$ \\
\hline $\mathrm{C} 12$ & 50 & 45 & 1.25 & $6.50 \pm 0.030^{\mathrm{b}}$ & $7.91 \pm 0.021^{\mathrm{f}}$ & $7.40 \pm 0.025^{\mathrm{de}}$ & $6.80 \pm 0.050^{c}$ & $6.89 \pm 0.081^{\mathrm{bc}}$ \\
\hline $\mathrm{C} 13$ & 50 & 50 & 0.75 & $6.80 \pm 0.055^{\mathrm{de}}$ & $8.10 \pm 0.055^{\mathrm{hi}}$ & $7.41 \pm 0.021^{\mathrm{de}}$ & $7.84 \pm 0.035^{\mathrm{jk}}$ & $7.18 \pm 0.026^{\mathrm{cd}}$ \\
\hline $\mathrm{C} 14$ & 50 & 50 & 1 & $7.40 \pm 0.030^{\mathrm{h}}$ & $8.00 \pm 0.035^{\mathrm{g}}$ & $7.80 \pm 0.025^{\mathrm{i}}$ & $7.63 \pm 0.031^{\mathrm{ghi}}$ & $6.98 \pm 0.131^{\mathrm{bc}}$ \\
\hline $\mathrm{C} 15$ & 50 & 50 & 1.25 & $7.20 \pm 0.030^{\mathrm{fg}}$ & $7.74 \pm 0.05$ & & $7.12 \pm 0.025^{\mathrm{d}}$ & $6.36 \pm 0.092^{\mathrm{a}}$ \\
\hline $\mathrm{C} 16$ & 50 & 55 & 0.75 & $7.64 \pm 0.021^{j}$ & $8.03 \pm 0.058^{\mathrm{gh}}$ & $8.05 \pm 0.050^{\mathrm{kl}}$ & $7.97 \pm 0.058^{\mathrm{kl}}$ & $6.82 \pm 0.055^{\mathrm{b}}$ \\
\hline $\mathrm{C} 17$ & 50 & 55 & 1 & $7.16 \pm 0.025^{\mathrm{f}}$ & $7.82 \pm 0.017^{\mathrm{e}}$ & $7.64 \pm 0.029^{\mathrm{gh}}$ & $7.19 \pm 0.023^{\mathrm{de}}$ & $6.82 \pm 0.576^{\mathrm{b}}$ \\
\hline $\mathrm{C} 18$ & 50 & 55 & 1.25 & $6.50 \pm 0.045^{\mathrm{b}}$ & $7.84 \pm 0.046^{\mathrm{ef}}$ & $7.65 \pm 0.046^{\mathrm{gh}}$ & $6.62 \pm 0.035^{\mathrm{b}}$ & $6.22 \pm 0.111^{\mathrm{a}}$ \\
\hline $\mathrm{C} 19$ & 55 & 45 & 0.75 & $8.15 \pm 0.050^{\mathrm{m}}$ & $8.15 \pm 0.061^{\mathrm{ij}}$ & $8.17 \pm 0.026^{1}$ & $8.15 \pm 0.050^{\mathrm{mn}}$ & $7.87 \pm 0.057^{\mathrm{g}}$ \\
\hline $\mathrm{C} 20$ & 55 & 45 & 1 & $7.87 \pm 0.055^{\mathrm{k}}$ & $8.01 \pm 0.023^{\mathrm{gh}}$ & $8.00 \pm 0.000^{\mathrm{k}}$ & $7.77 \pm 0.029^{\mathrm{ij}}$ & $7.66 \pm 0.052^{2^{\text {efg }}}$ \\
\hline $\mathrm{C} 21$ & 55 & 45 & 1.25 & $6.61 \pm 0.040^{c}$ & $8.04 \pm 0.053^{\mathrm{gh}}$ & $7.32 \pm 0.029^{\mathrm{cd}}$ & $7.31 \mathrm{v} \pm .341^{\mathrm{ef}}$ & $7.17 \pm 0.095^{\mathrm{cd}}$ \\
\hline $\mathrm{C} 22$ & 55 & 50 & 0.75 & $8.10 \pm 0.035^{\mathrm{m}}$ & $8.21 \pm 0.036^{\mathrm{j}}$ & $8.03 \pm 0.058^{\mathrm{kl}}$ & $8.08 \pm 0.029^{\mathrm{Imn}}$ & $7.39 \pm 0.049^{\text {def }}$ \\
\hline $\mathrm{C} 23$ & 55 & 50 & 1 & $7.63 \pm 0.046^{j}$ & $8.13 \pm 0.026^{\mathrm{ij}}$ & $7.95 \pm 0.050^{\mathrm{jk}}$ & $7.55 \pm 0.045^{\mathrm{gh}}$ & $6.89 \pm 0.610^{\mathrm{g}}$ \\
\hline $\mathrm{C} 24$ & 55 & 50 & 1.25 & $7.24 \pm 0.040^{\mathrm{g}}$ & $8.01 \pm 0.017^{g}$ & $7.47 \pm 0.035^{\text {ef }}$ & $7.20 \pm 0.045^{\mathrm{def}}$ & $7.36 \pm 0.096^{\mathrm{de}}$ \\
\hline $\mathrm{C} 25$ & 55 & 55 & 0.75 & $8.01 \pm 0.090^{1}$ & $8.03 \pm 0.118^{\text {gh }}$ & $7.82 \pm 0.070^{\mathrm{ij}}$ & $8.11 \pm 0.096^{\mathrm{Imn}}$ & $7.73 \pm 0.085^{\mathrm{g}}$ \\
\hline $\mathrm{C} 26$ & 55 & 55 & 1 & $8.37 \pm 0.035^{\mathrm{n}}$ & $8.19 \pm 0.035^{\mathrm{j}}$ & $8.00 \pm 0.000^{\mathrm{k}}$ & $8.20 \pm 0.040^{\mathrm{n}}$ & $6.99 \pm 0.125^{\mathrm{bc}}$ \\
\hline $\mathrm{C} 27$ & 55 & 55 & 1.25 & $7.66 \pm 0.040^{j}$ & $8.03 \pm 0.058^{\mathrm{gh}}$ & $7.64 \pm 0.021^{\mathrm{gh}}$ & $7.34 \pm 0.040 \mathrm{f}$ & $6.39 \pm 0.055^{\mathrm{a}}$ \\
\hline
\end{tabular}

Values are Mean \pm SD of three replications. ${ }^{a-n}$ Means with different superscripts vary significantly $(\mathrm{p}<0.05)$ within a column 
scores were obtained when curd and rice are in same ratio. Similar scores were obtained by Shah and Prajapati (2014) where increasing the salt level above $0.8 \%$ in fermented milk beverage, decreased the flavour scores. On the contrary, it was reported that addition of probiotic in free form did not cause any difference in the flavour score of yoghurt (Ribeiro et al., 2014).

The values of colour and appearance (CA) scores are presented in Table 5. Highest CA scores for PCR samples was obtained in a combination where 55 parts probiotic curd, 50 parts rice and $0.75 \%$ salt were used, whereas a combination with 45 parts probiotic curd, 55 parts rice and $1.25 \%$ salt obtained lowest score. Curd had highly significant $(\mathrm{p}<0.01)$ effect on the CA scores of PCR, i.e., increase in curd content increased the $\mathrm{CA}$ scores, on the other hand increase in rice content resulted in decrease in the CA scores as its effect was highly significant $(\mathrm{p}<0.01)$. It was observed that excess of curd in the product imparted it a gloss as compared to rice. Moreover, with more levels of rice as compared to the curd resulted in a dry appearance which was less acceptable to the panelists.

Highest body and texture (BT) score were obtained for the combination $\mathrm{C} 19$, where probiotic curd, rice and salt were present as 55 parts, 45 parts and $0.75 \%$ respectively, whereas lowest scores were obtained for C9 where 45 parts probiotic curd, 55 parts rice and $1.25 \%$ salt was added. It could be observed that BT scores of PCR were affected by all the three ingredients. Addition of probiotic curd had highly significant $(\mathrm{p}<0.01)$ effect on the BT scores of PCR. It was observed that increase in curd levels increased the BT values of PCR. Increase in the level of rice resulted in decrease in the BT scores of PCR significantly $(\mathrm{p}<0.05)$. Similar trend was observed in case of salt content where increase in salt content had highly significant $(\mathrm{p}<0.01)$ effect on the BT scores of PCR.

It was found that overall acceptability (OA) scores of PCR varied from 5.49 to 8.20 , where combination $\mathrm{C} 26$ with 55 parts probiotic curd,
50 parts rice and $1 \%$ salt obtained highest score, whereas lowest score was obtained in $\mathrm{C} 9$ with 45 parts probiotic curs, 55 parts rice and $1.25 \%$ salt. It was observed that all the ingredients had a highly significant $(\mathrm{p}<0.01)$ effect on the OA scores of PCR samples. On one hand, probiotic curd had a positive correlation with OA scores of PCR samples, whereas rice and salt content were negatively correlated with the OA content of PCR samples. In spite of the fact that highest OA score was obtained for $\mathrm{C} 26$ but there was no significant $(\mathrm{p}>0.05)$ difference in the OA scores of $\mathrm{C} 19$ in which it was found to be 8.15. Results obtained are contrary to those obtained from Prajapati (2015), where higher ratio of rice: milk was least acceptable.

In order to standardize the level of ingredients for preparation of curd rice, it is essential to consider the viability of the probiotic microorganism used. Viability of probiotic Lactobacillus rhamnosus CRD 11 is reported in Table 5. It was observed that viability of $L$. rhamnosus CRD 11 varied from 6.22 to $7.87 \log$ CFU/g where highest viability was reported in combination $\mathrm{C} 19$ with 55 parts probiotic curd, 45 parts rice and $0.75 \%$ salt. Lowest viability was reported in combination with 50 parts probiotic curd, 55 parts rice and $1.25 \%$ salt. As mentioned in Table 5 it was observed that curd level had a highly significant ( $\mathrm{p}<0.01$ ) effect on the viability of L. rhamnosus CRD 11 and increase in curd content led to increase in the viability. Changes in the rice level did not have any significant ( $p>0.05)$ effect on the viability of probiotic L. rhamnosus CRD 11. Changes in salt content in PCR had a negative and highly significant $(\mathrm{p}<0.01)$ effect on the probiotic L. rhamnosus CRD 11 viability in the product.

Even though standardized probiotic curd rice was obtained but probiotic count in the product was low. Hence, there exist scopes where same product can be made by encapsulating the probiotic bacteria in suitable complex which enhances their survival.

Encapsulated probiotic curd rice: With an 
intention to enhance the viability of probiotic in the product, encapsulation of probiotic Lactobacillus rhamnosus CRD 11 was carried out using emulsion technique. For the preparation of encapsulated probiotic curd rice (EPCR), probiotic curd was prepared using $2 \%$ dahi culture (Streptococcus thermophiles NCDC 324) along with $5 \%$ of encapsulated probiotic beads, which were added in the milk during inoculation. Curd thus obtained was used for the preparation of EPCR.

Sensory scores obtained from different combination of ingredients in EPCR are reported in Table 6. Highest score was awarded to treatment E22 having 55 parts probiotic curd, 50 parts rice and $0.75 \%$ salt, whereas lowest flavour scores were reported in treatment E18 where 50 parts probiotic curd, 50 parts rice and $1.25 \%$ salt was used. Curd and rice did not have any effect on the flavour scores of EPCR. Variation in the salt content had a highly significant $(p<0.05)$ effect on the flavour scores of EPCR.

Colour and appearance (CA) scores of different combination of ingredients of EPCR. Highest colour and appearance (CA) score was

Table 6. Sensory scores and probiotic count for encapsulated probiotic curd rice

\begin{tabular}{|c|c|c|c|c|c|c|c|c|}
\hline $\begin{array}{l}\text { Combi- } \\
\text { nation }\end{array}$ & Curd & Rice & Salt & Flavour & Colour & $\begin{array}{l}\text { Body and } \\
\text { Texture }\end{array}$ & $\begin{array}{l}\text { Overall } \\
\text { acceptability }\end{array}$ & $\begin{array}{l}\text { Probiotic } \\
\text { count (log } \\
\text { CFU/g) }\end{array}$ \\
\hline E1 & 45 & 45 & 0.75 & $7.81 \pm 0.056^{\mathrm{j}}$ & $8.19 \pm 0.040^{\mathrm{i}}$ & $7.86 \pm 0.069^{\mathrm{jk}}$ & $7.84 \pm 0.040^{\mathrm{m}}$ & $10.55 \pm 0.182^{1}$ \\
\hline E2 & 45 & 45 & 1 & $7.61 \pm 0.036^{\mathrm{ij}}$ & $8.12 \pm 0.025^{\mathrm{ij}}$ & $7.73 \pm 0.029^{\mathrm{hi}}$ & $7.48 \pm 0.029^{\mathrm{jk}}$ & $10.22 \pm 0.665^{\mathrm{k}}$ \\
\hline E3 & 45 & 45 & 1.25 & $6.48 \pm 0.275^{\mathrm{ab}}$ & $7.97 \pm 0.058^{\mathrm{h}}$ & $8.00 \pm 0.100^{1}$ & $7.18 \pm 0.020^{\mathrm{gh}}$ & $9.84 \pm 0.068^{\mathrm{ij}}$ \\
\hline E4 & 45 & 50 & 0.75 & $7.72 \pm 0.076^{\mathrm{ij}}$ & $8.12 \pm 0.029^{\mathrm{ij}}$ & $7.85 \pm 0.050^{\mathrm{jk}}$ & $7.62 \pm 0.025^{1}$ & $9.50 \pm 0.045^{\mathrm{g}}$ \\
\hline E5 & 45 & 50 & 1 & $7.73 \pm 0.029^{i j}$ & $8.11 \pm 0.101^{\mathrm{ij}}$ & $7.62 \pm 0.025^{\mathrm{fg}}$ & $7.48 \pm 0.040^{\mathrm{jk}}$ & $9.69 \pm 0.061^{\mathrm{hi}}$ \\
\hline E6 & 45 & 50 & 1.25 & $6.50 \pm 0.035^{\mathrm{ab}}$ & $7.50 \pm 0.000^{\mathrm{d}}$ & $7.51 \pm 0.066^{\mathrm{e}}$ & $6.47 \pm 0.036^{\mathrm{b}}$ & $9.21 \pm 0.031^{\text {ef }}$ \\
\hline E7 & 45 & 55 & 0.75 & $7.31 \pm 0.023^{g}$ & $8.19 \pm 0.032^{\mathrm{j}}$ & $7.68 \pm 0.040^{\mathrm{gh}}$ & $7.43 \pm 0.064^{j}$ & $8.86 \pm 0.062^{\mathrm{d}}$ \\
\hline E8 & 45 & 55 & 1 & $7.52 \pm 0.448^{\mathrm{hi}}$ & $8.02 \pm 0.126^{\mathrm{h}}$ & $7.86 \pm 0.046^{\mathrm{jk}}$ & $7.50 \pm 0.040^{\mathrm{jk}}$ & $8.64 \pm 0.097^{\mathrm{bc}}$ \\
\hline E9 & 45 & 55 & 1.25 & $6.74 \pm 0.036^{c}$ & $7.77 \pm 0.029^{\mathrm{f}}$ & $7.75 \pm 0.050^{\mathrm{hi}}$ & $6.77 \pm 0.026^{\mathrm{d}}$ & $8.32 \pm 0.049^{\mathrm{a}}$ \\
\hline E10 & 50 & 45 & 0.75 & $7.64 \pm 0.211^{\mathrm{ij}}$ & $7.75 \pm 0.050^{\mathrm{f}}$ & $8.05 \pm 0.062^{1}$ & $7.89 \pm 0.017^{\mathrm{m}}$ & $10.49 \pm 0.047^{1}$ \\
\hline E11 & 50 & 45 & 1 & $7.09 \pm 0.079^{\mathrm{ef}}$ & $7.50 \pm 0.050^{\mathrm{d}}$ & $7.33 \pm 0.035^{\mathrm{d}}$ & $7.04 \pm 0.053^{\mathrm{e}}$ & $10.14 \pm 0.053^{\mathrm{k}}$ \\
\hline E12 & 50 & 45 & 1.25 & $6.84 \pm 0.035^{\mathrm{cd}}$ & $7.87 \pm 0.025^{g}$ & $7.55 \pm 0.050^{\text {ef }}$ & $6.75 \pm 0.075^{\mathrm{cd}}$ & $9.82 \pm 0.051^{\mathrm{ij}}$ \\
\hline E13 & 50 & 50 & 0.75 & $7.03 \pm 0.030^{\mathrm{def}}$ & $7.83 \pm 0.025^{\mathrm{fg}}$ & $7.17 \pm 0.026^{\mathrm{c}}$ & $7.17 \pm 0.023^{\mathrm{gh}}$ & $9.68 \pm 0.070^{\mathrm{hi}}$ \\
\hline E14 & 50 & 50 & 1 & $6.83 \pm 0.025^{\mathrm{cd}}$ & $7.64 \pm 0.035^{\mathrm{e}}$ & $7.16 \pm 0.045^{\mathrm{c}}$ & $7.14 \pm 0.038^{\mathrm{g}}$ & $9.37 \pm 0.070^{\mathrm{fg}}$ \\
\hline E15 & 50 & 50 & 1.25 & $6.66 \pm 0.00^{\mathrm{bc}}$ & $7.55 \pm 0.050^{\mathrm{d}}$ & $7.16 \pm 0.040^{c}$ & $6.68 \pm 0.021^{\mathrm{c}}$ & $9.17 \pm 0.061^{\mathrm{e}}$ \\
\hline E16 & 50 & 55 & 0.75 & $6.73 \pm 0.025^{\mathrm{c}}$ & $7.50 \pm 0.045^{\mathrm{d}}$ & $7.13 \pm 0.036^{\mathrm{c}}$ & $7.06 \pm 0.060^{\text {ef }}$ & $8.78 \pm 0.095^{\mathrm{cd}}$ \\
\hline E17 & 50 & 55 & 1 & $7.38 \pm 0.025^{\mathrm{gh}}$ & $7.77 \pm 0.029^{f}$ & $7.54 \pm 0.032^{\mathrm{e}}$ & $7.03 \pm 0.058^{\mathrm{e}}$ & $8.92 \pm 0.059^{\mathrm{d}}$ \\
\hline E18 & 50 & 55 & 1.25 & $6.37 \pm 0.025^{\mathrm{a}}$ & $7.75 \pm 0.050^{\mathrm{f}}$ & $7.26 \pm 0.040^{\mathrm{d}}$ & $6.15 \pm 0.025^{\mathrm{a}}$ & $8.55 \pm 0.095^{b}$ \\
\hline E19 & 55 & 45 & 0.75 & $6.69 \pm 0.023^{\mathrm{bc}}$ & $6.67 \pm 0.023^{a}$ & $6.66 \pm 0.045^{\mathrm{a}}$ & $6.69 \pm 0.038^{c}$ & $10.39 \pm 0.051^{1}$ \\
\hline E20 & 55 & 45 & 1 & $6.99 \pm 0.012^{\mathrm{de}}$ & $7.15 \pm 0.050^{\mathrm{b}}$ & $7.05 \pm 0.050^{\mathrm{b}}$ & $7.05 \pm 0.050^{\mathrm{e}}$ & $9.88 \pm 0.010^{j}$ \\
\hline E21 & 55 & 45 & 1.25 & $7.17 \pm 0.026^{\mathrm{efg}}$ & $7.34 \pm 0.051^{\mathrm{c}}$ & $6.97 \pm 0.025^{\mathrm{b}}$ & $7.12 \pm 0.020^{\mathrm{fg}}$ & $9.50 \pm 0.090^{\mathrm{g}}$ \\
\hline E22 & 55 & 50 & 0.75 & $8.02 \pm 0.035^{\mathrm{k}}$ & $8.34 \pm 0.051^{\mathrm{k}}$ & $8.07 \pm 0.058^{1}$ & $8.02 \pm 0.029^{\mathrm{n}}$ & $9.51 \pm 0.055^{\mathrm{g}}$ \\
\hline E23 & 55 & 50 & 1 & $7.76 \pm 0.104^{j}$ & $8.03 \pm 0.058^{\mathrm{hi}}$ & $7.50 \pm 0.045^{\mathrm{e}}$ & $7.52 \pm 0.025^{\mathrm{k}}$ & $9.16 \pm 0.040^{\mathrm{e}}$ \\
\hline E24 & 55 & 50 & 1.25 & $7.23 \pm 0.025^{\mathrm{fg}}$ & $8.34 \pm 0.051^{\mathrm{k}}$ & $7.48 \pm 0.025^{\mathrm{e}}$ & $7.27 \pm 0.029^{\mathrm{i}}$ & $9.18 \pm 0.080^{\mathrm{e}}$ \\
\hline E25 & 55 & 55 & 0.75 & $7.72 \pm 0.053^{\mathrm{ij}}$ & $8.13 \pm 0.036^{\mathrm{j}}$ & $7.78 \pm 0.021^{\mathrm{ij}}$ & $7.90 \pm 0.076^{\mathrm{m}}$ & $9.83 \pm 0.064^{\mathrm{ij}}$ \\
\hline E26 & 55 & 55 & 1 & $7.53 \pm 0.031^{\mathrm{hi}}$ & $8.14 \pm 0.053^{\mathrm{j}}$ & $7.70 \pm 0.055^{\mathrm{ghi}}$ & $7.63 \pm 0.029^{1}$ & $9.54 \pm 0.080^{\mathrm{gh}}$ \\
\hline E27 & 55 & 55 & 1.25 & $6.39 \pm 0.056^{\mathrm{a}}$ & $7.53 \pm 0.072^{\mathrm{d}}$ & $7.90 \pm 0.070^{\mathrm{k}}$ & $7.23 \pm 0.035^{\mathrm{hi}}$ & $9.22 \pm 0.057^{\mathrm{ef}}$ \\
\hline
\end{tabular}

Values are Mean \pm SD of three replications. ${ }^{a-n}$ Means with different superscripts vary significantly $(\mathrm{p}<0.05)$ within a column 
given to E22 with 55 parts probiotic curd, 50 parts rice and $0.75 \%$ salt. Colour and appearance scores were significantly $(\mathrm{p}<0.05)$ affected by the changes in the levels of probiotic curd. With increase in the probiotic curd CA scores decreased, whereas with increase in rice content, CA scores of EPCR samples increased significantly $(\mathrm{p}<0.05)$. Ribeiro et al. (2014) prepared yoghurt in presence of free and encapsulated probiotic microorganisms, and reported that appearance of yoghurt in presence of microencapsulated probiotic was less acceptable. In the present study, CA scores decreased with increase in encapsulated probiotic curd, whereas, in presence of curd with probiotic in free form, CA scores increased.

It was found that BT scores of EPCR varied from 6.66 to 8.07 , where lowest BT score was given to E19 with 55 parts probiotic curd, 45 parts rice and $0.75 \%$ salt and highest $\mathrm{BT}$ score was obtained for E22 with 55 parts probiotic curd, 50 parts rice and $0.75 \%$ salt. Correlation of probiotic curd was highly significant $(\mathrm{p}<0.01)$ with the BT scores of EPCR. With increase in level of probiotic curd content BT scores decreased significantly $(\mathrm{p}<0.01)$. Salt had no effect on BT score of the product. As compared to curd rice with probiotic in free form, presence of encapsulated curd decreased the acceptance scores for body and texture. Probiotic microcapsules present in EPCR probably were perceivable during the sensory evaluation thus, affecting the texture of the product.

The OA scores for EPCR samples varied from 6.15 to 8.02. Highest score was obtained for E22 with 55 parts probiotic curd, 50 parts rice and $0.75 \%$ salt. Effect of change in salt content was highly significant $(\mathrm{p}<0.01)$ to the overall acceptability of the product, where increase in the level of salt decreased the OA scores significantly $(p<0.01)$. Presence of salt improves the flavour of any product; however, excess of salt reduces the overall acceptability. Shah and Prajapati (2014) reported reduction in overall acceptability of the carbonated fermented milk beverage upon addition of salt more than $0.8 \%$.
Viability of probiotic Lactobacillus rhamnosus CRD 11 was enumerated for each combination and the results obtained are presented in Table 6 The count of the probiotic microorganism varied from 8.32 to $10.55 \log \mathrm{CFU} / \mathrm{g}$. Highest score was obtained for E1 where 45 parts probiotic curd, 45 parts rice and $0.75 \%$ salt content. Viability of probiotic Lactobacillus rhamnosus CRD 11 for the combination E22 was $10.39 \log \mathrm{CFU} / \mathrm{g}$ which was similar to the viability of Lactobacillus rhamnosus CRD 11 obtained in combination E1. Increase in the levels of probiotic curd increased the probiotic count but the change was statistically nonsignificant. Decrease in the levels of rice led to significant $(\mathrm{p}<0.01)$ increase in the count of Lactobacillus rhamnosus CRD 11. Similar effect was observed with change in the levels of salt content. Increase in the salt content decreased the viability of probiotic Lactobacillus rhamnosus CRD 11 significantly $(\mathrm{p}<0.01)$.

\section{DISCUSSION}

The results revealed that microencapsulation undoubtedly improved the survival rate of probiotics in the presence of $3 \%$ inulin which probably enhanced the barrier effect of alginate capsules of L. rhamnosus against heat treatment. Hence, $3 \%$ inulin was selected for the preparation of encapsulated L. rhamnosus CRD 11. Abbaszadeh et al. (2014) in their study investigated the tolerance of L. rhamnosus against thermal treatment at $55^{\circ} \mathrm{C}, 60^{\circ} \mathrm{C}$ and $65^{\circ} \mathrm{C}$ and reported that bacteria loaded in alginate/chitosan complex showed higher heat stability as compared to free cells. Fareez et al. (2015) reported $95.5 \%$ and $94.1 \%$ survival rates of encapsulated probiotic at $75^{\circ} \mathrm{C}$ and $90^{\circ} \mathrm{C}$ respectively as compared to only $57.8 \%$ and $58.4 \%$ survival of free cells at same temperatures.

Regarding the effects of low $\mathrm{pH}$, similar trends were obtained from various other studies performed by different authors. Sabikhi et al. (2010) observed better survival rates of cells of encapsulated (using alginate and starch) L. acidophilus LA1 under artificial gastric 
conditions ( $\mathrm{pH} 1.5$ for $2 \mathrm{~h}$ ) than the free form of the same strain. Mandal et al. (2014) found significant increase in viability of probiotic cells after encapsulating them in alginate solutions without hindering the release of active cells from the capsule matrix. The results are in accordance with Afzaal et al. (2019) where only $3.57 \mathrm{log}$ reduction was observed in case of alginate beads as compared to $8.18 \mathrm{log}$ in free cells. Encapsulated probiotic have higher chances of surviving the gastrointestinal conditions as compared to free cells. Addition of inulin during the encapsulation of probiotic have significantly $(\mathrm{p}<0.05)$ increased the viability of bacterial population (Gandomi et al., 2016).

Increase in the salt content led to syneresis in the product which was imparted the undesirable body and texture to PCR. It was observed that increasing the $\mathrm{NaCl}$ level in products having casein gel formation, structure of casein gels tend to exhibit syneresis around pH 4.6 (Lucera et al., 2014). It was observed that highest probiotic viability was obtained with 55 parts of curd; this may be attributed to the fact that curd was the source of probiotics and increasing the ratio of curd in the final product increased the viable probiotic count. Also, probiotics cells are sensitive to high salt concentration due to its antimicrobial activity above certain level (Yilmaztekin et al., 2004). Teoh et al. (2011) reported that increase in the level of sodium concentration decreased the viability of $L$. acidophilus LA-5 and B. pseudocatenulatum G4.

Various studies have been conducted to estimate the viability of encapsulated probiotic bacteria in yoghurt based products which concluded that survivability of encapsulated probiotic organism is higher than that of free probiotic ( Kailasapathy, 2006; Ribeiro et al., 2014; Dianawati et al., 2016). As observed in the present study salt had a significantly $(\mathrm{p}<0.01)$ negative correlation with the viable probiotic counts. Similar results were reported by Teoh et al. (2011) where increase in salt concentratio ns decreased the viability of free probiotic L. acidophilus LA-5 and B. pseudocatenulatum G4 cells as compared to the encapsulated cells.
The decrease in viability of probiotic with high salt concentrations could be attributed to the high osmotic stress on bacterial cells (Sabikhi et al., 2010). However, the extent of reduction in viability of probiotic due to increase in salt concentration was less in EPCR as compared to PCR. This is attributed to the fact that encapsulation of probiotic with alginate matrix provided better protection to the cells.

It was observed that highest flavour scores for EPCR were obtained for same combination of ingredients as that of normal curd rice. This could be attributed to the fact that starter culture for acidification of milk was same. Probiotic Lactobacillus rhamnosus CRD 11 in EPCR was present in encapsulated form; hence probably it did not participate in the acidification of milk and did not affect the flavour of the product.

The findings of present study suggested that encapsulation of Lactobacillus rhamnosus CRD 11 in alginate complex in presence of inulin have significantly affected its viability under stressed conditions such as high temperature, low acid and high bile concentrations. Additions of these encapsulated beads in dahi have markedly enhanced the probiotic count in curd rice in comparison to its counterpart having probiotic in free form. Hence, it can be concluded that use of encapsulated probiotics in alginate complex in presence of prebiotics is necessary for better survibility of the microorganisms through curd rice.

Conflict of interest: Authors have no conflict of interest in this study.

Author's contribution: GG: Involved in investigation, data generation, preparing original draft; KK: Engaged in conceptualization, data curation, supervision and final editing; WGP: Involved in statistical analyses, methodology and editing.

\section{ACNOWKEDGEMENT}

This work is supported by ICAR-NDRI Institute Fellowship to the first author. The authors like to thank the Director, ICAR-NDRI, Karnal for patronizing the research work. 


\section{REFERENCES}

Abbaszadeh S, Gandomi H, Misaghi A, Bokaei S and Noori N, 2014. The effect of alginate and chitosan concentrations on some properties of chitosancoated alginate beads and survivability of encapsulated Lactobacillus rhamnosus in simulated gastrointestinal conditions and during heat processing: Alginate and chitosan concentration effects on encapsulated L. rhamnosus survival. J Sci Food Agric, 94(11): 2210-2216, doi: 10.1002/jsfa.6541

Afzaal M, Khan AU, Saeed F, Ahmed A, Ahmad M H et al., 2019. Functional exploration of free and encapsulated probiotic bacteria in yogurt and simulated gastrointestinal conditions. Food Sci Nutr, 7(12): 3931-3940, doi: 10.1002/fsn3.1254

Cook MT, Tzortzis G, Charalampopoulos D and Khutoryanskiy VV, 2012. Microencapsulation of probiotics for gastrointestinal delivery. J Control Release, 162(1): 56-67, doi: 10.1016/ j.jconrel.2012.06.003

Dianawati D, Mishra V and Shah NP, 2016. Survival of microencapsulated probiotic bacteria after processing and during storage: A review. Crit Rev Food Sci Nutr, 56(10): 1685-1716, doi: 10.1080/ 10408398.2013.798779

Ding WK and Shah NP, 2007. Acid, bile, and heat tolerance of free and microencapsulated probiotic bacteria. J Food Sci, 72(9): M446-M450, doi: 10.1111/j.1750-3841.2007.00565.x

FAO/WHO, 2002. Working Group on Drafting Guidelines for the Evaluation of Probiotics in food; FAO: London, ON, Canada, 30 April-1 May 2002. https://www.who.int/foodsafety/ fs_management/en/probiotic_guidelines.pdf [10th Sept., 2021]

Fareez IM, Lim SM, Mishra RK and Ramasamy K, 2015. Chitosan coated alginate-xanthan gum bead enhanced $\mathrm{pH}$ and thermotolerance of Lactobacillus plantarum LAB12. Int J Biol Macromol, 72: 1419-1428, doi: 10.1016/ j.ijbiomac.2014.10.054

Gandomi H, Abbaszadeh S, Misaghi A, Bokaie S and Noori N, 2016. Effect of chitosan-alginate encapsulation with inulin on survival of Lactobacillus rhamnosus GG during apple juice storage and under simulated gastrointestinal conditions. LWT-Food Sci Technol, 69: 365-371, doi: 10.1016/j.lwt.2016.01.064

Gibson GR and Roberfroid MB, 1995. Dietary modulation of the human colonic microbiota: introducing the concept of prebiotics. J Nutr,
125(6): 1401-1412, doi: 10.1093/jn/125.6.1401

Houghtby GA, Maturin LJ and Koenig EK, 1993. Microbiological count methods. In: Standard Methods for the Examination of Dairy Products. Marshall (Ed), Washington DC, USA, pp 213-246

Kailasapathy K, 2006. Survival of free and encapsulated probiotic bacteria and their effect on the sensory properties of yoghurt. LWT-Food Sci Technol, 39(10): 1221-1227, doi: 10.1016/ j.lwt.2005.07.013

Krasaekoopt W and Watcharapoka S, 2014. Effect of addition of inulin and galactooligosaccharide on the survival of microencapsulated probiotics in alginate beads coated with chitosan in simulated digestive system, yogurt and fruit juice. LWTFood Sci Technol, 57(2): 761-766, doi: 10.1016/ j.lwt.2014.01.037

Lucera A, Mastromatteo M, Conte A, Zambrini AV, Faccia M et al., 2014. Effect of active coating on microbiological and sensory properties of fresh mozzarella cheese. Food Packag Shelf Life, 1(1): 25-29, doi: 10.1016/j.fpsl.2013.10.002

Mandal S, Hati S, Puniya AK, Khamrui K and Singh K, 2014. Enhancement of survival of alginateencapsulated Lactobacillus casei NCDC 298: enhancement of survival of alginate-encapsulated L. casei. J Sci Food Agric, 94(10): 1994-2001, doi: $10.1002 /$ jsfa.6514

Mandal S, Puniya AK and Singh K, 2006. Effect of alginate concentrations on survival of microencapsulated Lactobacillus casei NCDC298. Int Dairy J, 16(10): 1190-1195, doi: 10.1016/ j.idairyj.2005.10.005

Markowiak P and Śliżewska K, 2017. Effects of probiotics, prebiotics, and synbiotics on human health. Nutrients, 9(9):, 1021-1050, doi: 10.3390/ nu9091021

Nedovic V, Kalusevic A, Manojlovic V, Levic S and Bugarski B, 2011. An overview of encapsulation technologies for food applications. Procedia Food Sci, 1: 1806-1815, doi: 10.1016/j.profoo. 2011.09.265

Ohashi Y and Ushida K, 2009. Health-beneficial effects of probiotics: its mode of action. Anim Sci J, 80(4): 361-371, doi: 10.1111/j.1740-0929.2009. 00645.x

Ozyurt VH and Ötles S, 2014. Properties of probiotics and encapsulated probiotics in food. Acta Sci Pol Technol Aliment, 13(4): 413-424

Peredo AG, Beristain CI, Pascual LA, Azuara E and Jimenez M, 2016. The effect of prebiotics on the 
viability of encapsulated probiotic bacteria. LWTFood Sci Technol, 73: 191-196, doi: 10.1016/ j.lwt.2016.06.021

Praepanitchai OA, Noomhorm A and Anal AK, 2019. Survival and behavior of encapsulated probiotics (Lactobacillus plantarum) in calcium-alginate-soy protein isolate-based hydrogel beads in different processing conditions ( $\mathrm{pH}$ and temperature) and in pasteurized mango juice. Bio Med Res Int, 20(2): 78-86, doi: 10.1155/2019/9768152

Prajapati RK, 2015. Process optimization for production of curd rice with extended shelf life. M.Sc. thesis in Dairy Technology, submitted to ICAR-NDRI (Deemed University), Karnal (Haryana), India

Rao AV, Shiwnarain N and Maharaj I, 1989. Survival of microencapsulated Bifidobacterium pseudolongum in simulated gastric and intestinal juices. Can Inst Food Technol J, 22(4): 345-349, doi: 10.1016/S0315-5463(89)70426-0

Ribeiro MCE, Chaves KS, Gebara C, Infante FNS, Grosso CRF et al., 2014. Effect of microencapsulation of Lactobacillus acidophilus LA-5 on physicochemical, sensory and microbiological characteristics of stirred probiotic yoghurt. Food Res Int, 66: 424-431, doi: 10.1016/ j.foodres.2014.10.019

Rokka S and Rantamäki P, 2010. Protecting probiotic bacteria by microencapsulation: challenges for industrial applications. Eur Food Res Technol, 231(1): 1-12, doi: 10.1007/s00217-010-1246-2

Sabikhi L, Babu R, Thompkinson DK and Kapila S, 2010. Resistance of microencapsulated Lactobacillus acidophilus LA1 to processing treatments and simulated gut conditions. Food Bioproc Tech, 3(4): 586-593, doi: 10.1007/ s11947-008-0135-1

Shah N and Prajapati JB, 2014. Effect of carbon dioxide on sensory attributes, physico-chemical parameters and viability of probiotic $L$. helveticus MTCC 5463 in fermented milk. J Food Sci Technol, 51(12): 3886-3893, doi: 10.1007/ s13197-013-0943-9

Sheu TY, Marshall RT and Heymann H, 1993. Improving survival of culture bacteria in frozen desserts by microentrapment. J Dairy Sci, 76(7): 1902-1907, doi: 10.3168/jds.S0022-0302(93) 77523-2

Teoh P, Mirhosseini SH, Mustafa S and Manap MYA, 2011. Tolerance of free and encapsulated probiotics towards heat treatment and high sodium concentration. J Food Agri Environ, 9(1): 69-73

Yilmaztekin M, Ozer BH and Atasoy F, 2004. Survival of Lactobacillus acidophilus LA-5 and Bifidobacterium bifidum BB-02 in white-brined cheese. Int J Food Sci Nutr, 55(1): 53-60, doi: $10.1080 / 09637480310001642484$

Received - 18.09.2021, Accepted-20.11.2021, Published-01.12.2021

Section Editor: Prof. M. K. Sanyal, Member, Editorial Board 